\title{
ANALISIS LOYALITAS PELANGGAN DI PT NUTRIFOOD, KOTAMADYA BOGOR
}

\author{
Samsudin \\ Institut Ilmu Sosial dan Manajemen STIAMI \\ Email:samsudin@stiami.ac.id
}

\section{ARTIKEL INFO}

ABSTRACT

$\begin{array}{lr}\text { Keywords: } & \text { Customer } \\ \text { Loyalty, } & P T \quad \text { Nutrifood, } \\ \text { Products, } & \text { Quality, Loyality }\end{array}$

\section{PENDAHULUAN}

Memasuki era milenimum ke 3, setiap perusahaan dihadapkan dengan beban persaingan yang sangat ketat, mengingat tumbuh suburnya jumlah perusahaan yang sejenis. Untuk dapat tetap eksis, maju dan berkembang serta keluar sebagai pemenang dalam era persaingan global, setiap perusahaan dituntut untuk memiliki keunggulan komparatif dan kompetitif yang tinggi. Salah satu diantaranya adalah strategi bagaimana mempertahankan agar konsumen atau pelanggan tetap loyal dan setia dengan produk yang mereka tawarkan.

Tidaklah mudah untuk menjadikan pelanggan tetap loyal, memberikan pelayanan yang prima saja tidaklah cukup, tetapi diperlukan strategi yang komprehensif intergral dari hulu ke hilir dalam setiap aspek. Bagi setiap perusahaan, kelangsungan bisnis, menciptakan pelanggan yang loyal menjadi agenda penting mengingat biaya retensi pelanggan jauh lebih efisien dibandingkan mendapatkan pelanggan baru.

Dengan kondisi market yang dinamis, produsen gencar mengeluarkan produk baru, dan dikombinasikan dengan tren masyarakat yang senang mencoba, maka menciptakan loyalitas merupakan tugas yang sangat berat. Loyalitas akan menjadi legenda dalam dunia service karena konsumen yang gemar mencoba hal yang baru.

Dengan memahami tren konsumen yang senang mencoba hal yang baru, maka produsen pun harus semakin rajin atau cepat untuk menghasilkan produk baru yang inovatif. Jika produsen "tetap 
dalam mempertahankan produk lama (status quo)" dengan produk yang absolete, bagaimana mungkin mengharapkan adanya loyalitas.

Demikian juga halnya yang terjadi di PT Nutrifood, dimana PT Nutrifood merasakan fenomena tersebut dan sadar betul kecenderungan konsumen untuk selalu mencoba produk baru. Muncul kekahwatiran apabila suatu waktu konsumen beralih ke produk sejenis yang dihasilkan oleh perusahaan lain. Kekahwatiran tersebut sangat beralasan karena, dewasa ini persaingan bisnis begitu ketat, banyak produk yang hampir sama beredar di pasaran, sehingga memungkinkan bagi konsumen untuk memilih yang terbaik, baik dari sisi kualitas barang, harga, rasa, kemasan maupun lainnya.

Kecenderungan tersebut secara tidak langsung menjadi ancaman bagi PT Nutrifood, yang tidak ingin konsumen beralih ke produk lain. Beragai cara telah dilakukan PT Nutriffod untuk mempertahakan atau menjaga agar konsumen tetap setia membeli produk yang ditawarkan PT Nutriffod di pasaran. Beberapa cara yang dilakukan untuk menjaga loyalitas konseumen diantaranya adalah dengan cara memperbaiki kualitas produk secara terus menerus berdasarkan masukan, informasi atau keluhan konsumen atas setiap kelemahan produk yang ada. Kelemahan-kelemahan yang ada terus menerus dievaluasi dan diperbaiki.

Hal lainnya adalah menentukan harga agar sesuai dengan harga pasar. Nutrifood selalu berhatihati untuk tidak menetapkan harga terlalu jauh di bawah atau di atas harga produk sejenis di pasaran. Terlalu rendah menentukan harga akan mengurangi pendapatan, begitu pula jika terlalu tinggi akan berdampak kurang atau tidak diminatinya produk tersebut sehingga sulit untuk terjual.Aspek lainnya yang menjadi pertimbangan PT Nutrifood adalah kesehatan produk. Pertimbangan tersebut didasarkan bahwa saat ini dalam menentukan pilihan pembeliannya, konsumen selalu dengan pertimbangan jangka panjang dan lebih sadar lingkungan serta sadar kesehatan. Intinya adalah konsumen akan selalu teliti dan hati-hati dalam menentukan pilihan pembelian barang. Sekali konsumen telah menentukan piihan yang tepat maka ia akan cenderung untuk loyal. Pada umumnya konsumen yang loyal terhadap produk yang dibelinya akan diwujudkan pada perilaku untuk mengkonsumsi ulang atau ada niat untuk melakukan pembelian dan mengkonsumsinya kembali. Sedangkan perilaku konsumen yang tidak loyal pada produk yang dibelinya akan diwujudkan perilaku yang berubah (tidak konstan) artinya keputusan konsumen berpindah merek cenderung semakin tinggi.

Loyalitas konsumen adalah hubungan emosional pelanggan dengan perusahaan, dibuktikan dengan mentransformasikan perilaku pembelian berulang. Salah satu cara untuk meningkatkan loyalitas pelanggan adalah dengan memberikan pelayanan yang berkualitas baik, yang diharapkan dapat membuat pelanggan untuk kembali melakukan transaksi. Banyak sekali faktor yang mempengaruhi loyalitas adalah kepuasan pelanggan, kualitas, citra, dan rintangan untuk berpindah. Untuk menciptakan kesetiaan pelanggan tidak sekedar memberikan kepuasan saja tetapi perusahaan perlu menambahkan nilai dari produk yang ditawarkan karena konsumen yang puas belum menjamin pelanggan melakukan pembelian ulang.

Apabila seorang pelanggan sudah percaya seutuhnya terhadap suatu perusahaan maka ia memiliki hubungan jangka panjang dengan perusahaan, sehingga pelanggan tidak terlalu sensitif terhadap harga yang ditetapkan untuk jasa layanan perusahaan dibandingkan dengan pelanggan biasa. Jangka waktu yang lama tidak dapat digunakan sebagai ukuran loyalitas pelanggan akan suatu produk atau jasa. Memahami manfaat loyalitas pelanggan, maka menjadi penting bagi pemasar untuk menumbuhkannya di benak konsumen. Namun, membangun loyalitas tidak semudah seperti menambahkan sesuatu sebagai pelengkap. Loyalitas pelanggan harus terintegrasi dengan strategi dasar bisnis. Loyalitas pelanggan didapat dari penyampaian nilai superior secara konsisten yang dapat ditumbuhkan dan diperkuat dengan memberikan kualitas layanan yang superior.

\section{KAJIAN LITERATUR}

\section{Pengertian Loyalitas Pelanggan}

Pelanggan adalah seseorang yang menjadi terbiasa untuk membeli dari produsen atau penyedia jasa layanan. Kebiasaan itu terbentuk melalui pembelian dan interaksi yang sering selama periode waktu tertentu. Tanpa adanya sejarah perjalanan hubungan yang kuat dan pembelian berulang, konsumen tersebut bukanlah pelanggan, atau lebih mudah disebut pembeli. Pelanggan sejati tumbuh seiring dengan waktu. 
Loyalitas pelanggan sangat diperlukan di dalam keberlangsungan suatu perusahaan, dimana citra, kepercayaan, reputasi perusahaan yang baik merupakan faktor penting dalam terciptanya loyalitas nasabah. Pelanggan disebut sebagai aset perusahaan, yakni pihak yang membiayai perusahaan. Loyalitas dari nasabah terhadap perusahaannya mutlak dipertahankan demi terciptanya hubungan yang saling menguntungkan di antara kedua belah pihak. Sehingga perusahaan harus selalu fokus kepada pelanggan, untuk memenuhi harapan, keinginan dan kebutuhan serta menghargai mereka sehingga dapat menjalin hubungan sampai ke tingkat emosional di antara pelanggan dengan perusahaan.

Gremler dan Brown (1996) mendefinisikan loyalitas pelanggan sebagai :

"the degree to which a customer exhibits repeat purchasing behavior from a service provider, possesses a positive attitudinal disposition toward the provider, and consider using only this provider when a need for this service is exists". (Kheng, Mahamad, Ramayah, 2010:58).

Kemudian pada tahun 1999, Oliver mendefinisikan loyalitas pelanggan sebagai :

"a deeply held commitment to rebuy or repatronize a preferred product or service consistently in future, thereby causing repetitive same-brand or same brand-set purchasing, despite situational influences and marketing efforts having the potential to cause switching behaviour". (Boora \& Singh, 2011:153).

Griffin menambahkan bahwa loyalitas pelanggan merupakan perilaku pembelian yang didefinisikan sebagai pembelian nonrandom yang diungkapkan dari waktu ke waktu oleh beberapa unit pengambilan keputusan (Griffin, 2005:5). Non random yang dimaksud adalah prasangka spesifik mengenai apa yang dibeli dan dari siapa. Sedangkan unit pengambilan keputusan menunjukkan bahwa keputusan membeli mungkin dilakukan oleh lebih dari satu orang. Pada kasus demikian, keputusan pembelian dapat menunjukkan kompromi yang dilakukan seseorang dalam unit dan dapat menjelaskan mengapa ia kadang-kadang tidak loyal pada produk atau jasa yang paling disukainya.

\section{Konsep Loyalitas}

Literatur-literatur pemasaran menyatakan bahwa loyalitas dapat dipahami sebagai behavioural loyalty dan attitudinal loyalty (Aaker 1991; Assael 1998; Day 1969, Jacoby \& chesnut 1978; Jacoby \& Kyner 1973; Oliver 1999; Tucker 1964; Chaudhuri \& Holbrook, 2001:82) dimana menjelaskan sebagai berikut : 1). Behavioural Loyalty. Loyalitas dapat dipahami sebagai konsep pada runtutan pembelian, proporsi pembelian, probabilitas pembelian, dan pembelian di masa depan berdasarkan pembelian di masa lampau. Behavioural loyalty juga dapat diukur secara mudah melalui teknik observasi dari transaksi berulang (atau persentase total transaksi dalam satu kategori, atau total pengeluaran dalam suatu kategori) (Morgan \& Hunt;1994, Jumaev, Kumar \& Hanaysha; 2012:37). Aspek behavioural direpresentasikan dengan pembelian berulang produk atau jasa, termasuk pembelian produk yang berbeda dari suatu perusahaan (Feick, Lee, \& Lee, 2001; Akbar \& Parvez, 2009), 2). Attitudinal Loyalty. Pendekatan ini dipahami sebagai komitmen psikologis pelanggan, sikap keberpihakan, itikad baik terhadap produk atau jasa tertentu (Kim et. al;2004, Boora \& Singh; 2011:158). Komponen ini mewakili gagasan seperti niat pembelian kembali, pembelian produk atau jasa tambahan dari perusahaan yang sama, keinginan untuk merekomendasikan kepada orang lain, dan menunjukkan komitmen kepada perusahaan dengan tidak berpindah ke kompetitor (Cronin \& Taylor, 1992; Narayandas, 1996; Prus \& Brandt, 1995; Akbar \& Parvez, 2009) dan kerelaan untuk membayar dengan harga premium (Zeithaml, Berry, \& Parasuraman, 1996; Akbar \& Parvez, 2009).

\section{Tingkat Loyalitas Pelanggan}

Oliver (1997) mengemukakan empat tahap loyalitas yaitu sebagai berikut: 1). Tingkat Pertama: Loyalitas Kognitif. Loyalitas kognisi merupakan informasi berdasarkan biaya, keuntungan dan kualitas selama proses pengambilan keputusan pembelian. Pelanggan kemungkinan akan beralih ke penyedia produk atau jasa lain yang menawarkan proses dan keuntungan yang lebih baik. Dalam konteks ini, biaya dan keuntungan diartikan sebagai nilai yang dirasakan dari kulitas jasa yang dirasakan. Karena hanya sebatas kognisi maka loyalitas ini tidak cukup kuat untuk membuat konsumen tetap loyal, 2). Tingkat Kedua: Loyalitas Afektif. Loyalitas afektif mengaitkan antara kesukaan dan pengalaman kepuasan. Persoalan kepuasan dan ketidakpuasan memiliki dampak langsung pada perilaku dan perubahan perilaku. Tetapi, kepuasan belum menjamin adanya loyalitas, karena kepuasan konsumen berkorelasi tinggi dengan niat membeli ulang di masa mendatang. Niat, 
bahkan pembelian berulang belum menunjukkan adanya loyalitas, hanya dapat dianggap sebagai tanda awal munculnya loyalitas. Loyalitas pada tahap ini jauh lebih sulit dirubah, karena loyalitas sudah masuk ke benak pelanggan. Pada tahap ini loyalitas pelanggan ditentukan oleh informasi terkait dengan penawaran seperti harga, kualitas dan lain-lain, 3). Tingkat Ketiga: Loyalitas Konatif. Tahap ini merupakan tahap dimana pelanggan memiliki komitmen untuk membeli. Salah satu dimensi penting adalah getok tular (word of mouth), dimana pelanggan tidak hanya akan berkunjung lagi ke toko atau perusahaan tertentu, tetapi juga akan mendorong sanak saudara, teman dan kolega untuk berlangganan pada perusahaan favorit. Pelanggan tidak hanya berkomitmen untuk membeli tetapi juga percaya. Loyalitas kategori ini akan terlindungi dari aktivitas pemasaran pesaing, perusahaan tidak akan bersusah-susah menghabiskan waktu, melakukan pencarian informasi dan evaluasi. Kegagalan penyampaian jasa berulang menjadi faktor terkuat dalam penurunan loyalitas konatif. Pelanggan akan lebih memilih alternatif lain jika mereka sering merasakan kegagalan penyampaian jasa, 4). Tingkat Keempat: Loyalitas Tindakan. Niat melakukan adalah kondisi yang mengarah pada kesiapan bertindak dan pada keinginan untuk mengatasi hambatan untuk mencapai tindakan tersebut. Dengan kata lain, tindakan mendatang sangat didukung oleh pengalaman mencapai sesuatu dan penyelesaian hambatan.

\section{Dimensi dan Indikator Loyalitas Konsumen}

Lovelock dan Wirtz (2007) menyebutkan loyalitas dipakai untuk menggambarkan suatu keinginan pelanggan untuk terus melakukan suatu pola ulangan pada jangka waktu yang lama dan merekomendasikan produk atau jasa yang dimiliki perusahaan kepada teman dan asosiasi-asosisasi.

Menurut Griffin (2005:33-34) konsumen yang loyal merupakan aset penting bagi perusahaan, hal ini dapat dilihat dari karateristik yang dimilikinya yaitu sebagai berikut: 1). Melakukan pembelian berulang secara teratur. Loyalitas biasanya dihubungkan dengan perilaku membeli. Pelanggan yang puas akan suatu jasa pada pembelian pertama akan melakukan pembelian berulang. Ketika kepuasan timbul maka akan muncul kesetiaan untuk terus menggunakan jasa layanan tersebut secara berulang dan dengan waktu tertentu secara teratur, 2). Membeli di luar lini produk / jasa. Pelanggan bukan hanya membeli satu jenis jasa tetapi mereka juga membeli jasa layanan lain yang terkait dengan produk atau jasa utama yang telah dikonsumsinya. Contoh nyata pada perusahaan, misalkan seorang pelanggan yang loyal telah memiliki tabungan yang digunakan untuk transaksi harian, tetapi dia akan membuka rekening lain yang digunakan untuk investasi jangka panjang, mengikuti program-program loyalitas yang diadakan oleh perusahaan tersebut atau menggunakan jasa layanan lainnya, 3). Mereferensikan kepada orang lain. Pelanggan yang telah percaya dan setia merupakan asset paling berharga bagi perusahaan. Salah satu karakteristik unik promosi dalam bisnis jasa adalah pentingnya referensi dari orang lain. Pelanggan yang setia akan dengan rela menceritakan kebaikan-kebaikan jasa layanan yang telah diberikan tanpa adanya timbal balik dari perusahaan karena telah mereferensikan kepada orang lain. Pelanggan seringkali menginformasikan kepada pelanggan potensial lainnya tentang pengalaman mereka. Rekomendasi personal seringkali merupakan sumber informasi yang paling disukai. Konsumen yang membeli karena referensi pribadi cenderung lebih loyal dibanding mereka yang membeli karena iklan (Reichheld \& Cook, 1996:5), dan 4). Menunjukkan kekebalan dari daya tarik produk sejenis dari pesaing. Pelanggan dengan loyalitas yang kuat tidak memiliki keinginan untuk meakukan pencarian terhadap alternatif lain, melupakan keberadaan pilihan lain dan cenderung menunjukkan kekebalan terhadap produk atau jasa sejenis. Pelanggan yang setia akan menganggap bahwa produk atau jasa yang biasa dikonsumsi walaupun ada pesaing sejenis yang menawarkan kelebihan lebih seperti biaya yang lebih rendah.

Konsep dasar dan tujuan utama dalam sebuah bisnis tidak hanya mencapai keuntungan semata tetapi menciptakan pelanggan. Para pelanggan yang dipuaskan merupakan sumber keuntungan bagi pemasar. Kualitas layanan memberikan dorongan khusus bagi para konsumen untuk menjalin ikatan relasi saling menguntungkan dalam jangka panjang dengan perusahaan. Ikatan emosional semacam ini memungkinkan perusahaan untuk memahami harapan dan kebutuhan spesifik konsumen.

Membangun dasar loyalitas pelanggan tidak semudah melakukan pemasangan iklan. Hal ini harus terintegrasi dengan strategi bisnis yang dimiliki perusahaan Loyalitas pelanggan didapatkan dari konsistensi penyampaian jasa yang bernilai superior (Reichheld, 1996:3). Ketika berhasil diaplikasikan, kualitas layanan yang superior akan mendorong pelanggan untuk melakukan pembelian dalam jumlah yang lebih besar karena kualitas layanan yang baik akan mempengaruhi persepsi 
konsumen dan ketika pelanggan senang maka ia akan cenderung memberikan persepsi positif atas jasa layanan. Kotler mengatakan bahwa kualitas jasa harus dimulai dari kebutuhan konsumen dan berakhir dengan kepuasan konsumen serta persepsi positif terhadap kualitas layanan (Fandy Tjiptono \& Gregorius Chandra; 2005:115).

\section{Kerangka Pemikiran}

Berdasarkan uraian yang telah disampaikan sebelumnya, maka model penelitian yang dibuat sebagaimana yang berikut di bawah ini :

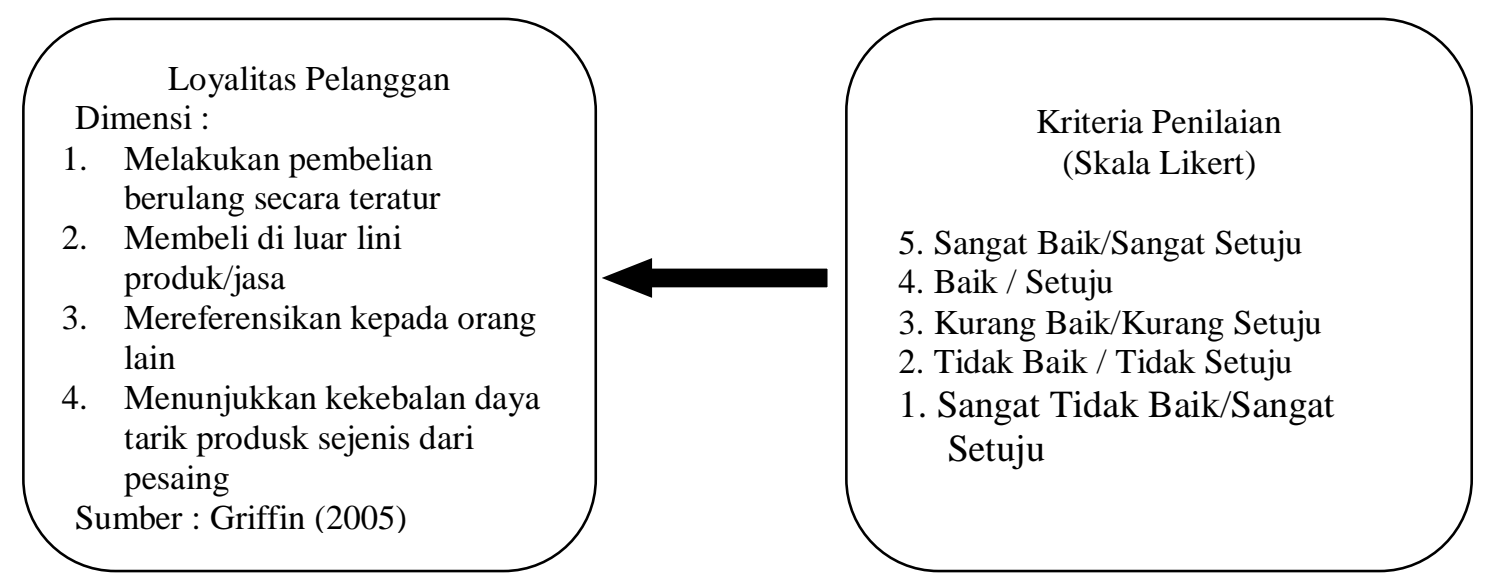

\section{METODOLOGI PENELITAN}

\section{Jenis Penelitian}

Jenis penelitian ini adalah penelitian deskriptif dengan pendekatan kuantitatif. Adapun penegrtian penelitian deskriptif adalah penelitian yang dilakukan untuk mengetahui nilai variable mandiri, baik satu variable atau lebih (independen) tanpa membuat perbandingan atu menghubungkannya dengan variable lain (Sugiyono, 2003, 11). Sedangkan penelitian kuantitatif adalah penelitian yang menekankan analisisnya pada data numerical atau angka yang diperoleh dengan metode statistik serta dilakukan pada penelitian inferensial atau dalam rangka pengujian hipotesis sehingga diperoleh signifikansi hubungan antara variabel yang diteliti.

\section{Operasionalisasi Variabel}

Operasionalisasi terdiri dari 2 unsur yaitu definisi operasional dan kisi-kisi variable. Yaitu : 1). Definisi Operasional. Operasionalisiasi adalah definisi beberapa variable dengan memberikan arti atau spesifikasi kegiatan atau beberapa petunjuk bagaimana suatu varaibel dapat diukur dan atau dapat diamati sesuai dengan fakta di lapangan, 2). Kisi-kisi Variabel. Kisi-kisi variable adalah hasil pemilahan variable-variabel penelitian. Langkah awal adalah memeilah variable menjadi beberapa dimensi. Variabel-variabel penelitian social umumnya memiliki lebih dari satu dimensi. Semakin lengkap dimensi suatu variable yang dapat diukur semakin baik ukuran yang dihasilkan. Ukuran variable dikatakan lengkap apabila dimensi-dimensi yang telah ditentukan tersebut tercakup oleh instrument pengukur.

Variabel dari penelitian berisi Kisi-kisi Variabel Penelitian yang memuat deskripsi dimensi (subvariabel), setiap dimensi dirumuskan indikatornya untuk kemudian menjadi item angket (quisionery). Operasionalisasi variable tersebut adalah sebagai berikut

Tabel 1. Kisi-Kisi Variabel

\begin{tabular}{|c|c|c|c|c|c|}
\hline No & Varibel & Dimensi & Indikator & $\begin{array}{c}\text { No } \\
\text { Item }\end{array}$ & $\begin{array}{c}\text { Jumlah } \\
\text { item }\end{array}$ \\
\hline 1 & $\begin{array}{l}\text { Loyalitas } \\
\text { Pelanggan }\end{array}$ & $\begin{array}{l}\text { 1. Melakukan } \\
\text { pembelian } \\
\text { berulang secara } \\
\text { teratur }\end{array}$ & $\begin{array}{l}\text { 1. Puas terhadap produk } \\
\text { 2. Pembelian berulang }\end{array}$ & $1,2,3$ & 3 \\
\hline
\end{tabular}




\begin{tabular}{|c|c|c|c|c|c|}
\hline No & Varibel & Dimensi & Indikator & $\begin{array}{c}\text { No } \\
\text { Item }\end{array}$ & $\begin{array}{c}\text { Jumlah } \\
\text { item }\end{array}$ \\
\hline & & & 3. Kesetiaan & \multirow{3}{*}{4} & \multirow{3}{*}{ Nom } \\
\hline & $\begin{array}{l}\text { Zeithaml, } \\
\text { Bitner \& } \\
\text { Gremler }\end{array}$ & $\begin{array}{l}\text { 2. Membeli di luar li } \\
\text { ni produk/jasa }\end{array}$ & $\begin{array}{l}\text { Menggunakan produk } \\
\text { layanan lainnya }\end{array}$ & & \\
\hline & $\begin{array}{l}(2006: 54) \\
\text { dan Griffin } \\
(2005: 3234)\end{array}$ & $\begin{array}{l}\text { 3. Mereferensikan } \\
\text { kepada orang lain }\end{array}$ & $\begin{array}{l}\text { 1. Rela menceritakan } \\
\text { kebaikan-kebaikan jasa } \\
\text { layanan yang telah } \\
\text { diberikan tanpa adanya } \\
\text { timbal balik dari } \\
\text { perusahaan }\end{array}$ & & \\
\hline & & & $\begin{array}{l}\text { 2. Merekomendasikan } \\
\text { produk kepada orang } \\
\text { lain }\end{array}$ & \multirow[t]{2}{*}{$5,6,7$} & \multirow[t]{2}{*}{3} \\
\hline & & & $\begin{array}{l}\text { 3. Seringkali } \\
\text { menginformasikan } \\
\text { kepada yang pelanggan } \\
\text { potensial lainnya } \\
\text { tentang pengalaman } \\
\text { mereka. }\end{array}$ & & \\
\hline & & \multirow[t]{3}{*}{$\begin{array}{l}\text { 4. Menunjukkan } \\
\text { kekebalan daya } \\
\text { tarik produk } \\
\text { sejenis dari } \\
\text { pesaing }\end{array}$} & $\begin{array}{lr}\text { 1. Tidak } & \text { memiliki } \\
\text { keinginan } & \text { untuk } \\
\text { melakukan pencarian } & \text { terhadap alternatif lain, }\end{array}$ & \multirow{3}{*}{$8,9,10$} & \multirow{3}{*}{3} \\
\hline & & & $\begin{array}{l}\text { 2. Melupakan keberadaan } \\
\text { pilihan lain }\end{array}$ & & \\
\hline & & & $\begin{array}{l}\text { 3. Cenderung } \\
\text { menunjukkan } \\
\text { kekebalan terhadap } \\
\text { produk atau jasa } \\
\text { sejenis dari perusahaan } \\
\text { lain. }\end{array}$ & & \\
\hline
\end{tabular}

\section{Teknik Pengumpulan Data}

Pendekatan yang digunakan dalam penelitian ini adalah pendekatan survei yaitu penelitian yang mengambil sampel dari satu populasi dan menggunakan kuesioner sebagai alat pengumpulan data yang pokok (Singarimbun, $1995: 3$ ).

\section{Teknik Sampling}

\section{Populasi}

Populasi adalah keseluruhan subyek penelitian (Arikunto, 2006: 130).Dengan menetapkan populasi, inidimaksudkan agar suatu penelitian dapat mengukur sesuatu sesuai dengan kasusnya dan tidak berlebihan dengan populasi yang diacu. Adapun jumlah populasi pelanggan PT Nutrifood yang ada di lapangan saat ini berjumlah sekitar lebih 30.000 pelanggan

\section{Sampel}

Yang dimaksud dengan sampel adalah sebagian atau wakil populasi yang diteliti (Arikunto, 2006: 131). Sesuai dengan pemahaman diatas, maka sampel dalam penelitian ini adalah sebagian atau wakil yang sudah ditentukan. 


\section{Teknik pengambilan sampel}

Teknik pengambilan sampel dalam penelitian ini adalah menggunakan metode accidential sampling, yaitu pengambilan sampel didasarkan pada kenyataan bahwa mereka kebetulan muncul. Sugiyono (2007).

Jumlah sample diambil dengan menggunakan rumus Slovin yaitu $: \mathrm{n}=\mathrm{N} /\left(1+\mathrm{Ne}^{2}\right)$, Dimana $: \mathrm{n}$ $=$ jumlah sampel, $\mathrm{N}=$ Jumlah populasi, $\mathrm{e}=$ tingkat kesalahan $(10 \%)$.

Jumlah populasi pelanggan selama kurun waktu 3 bulan penelitian dari bulan Oktober, November dan Desember adalah sebanyak 343 orang pelanggan, maka jumlah sample adalah : $\mathrm{n}=$ $343 /\left(1+343(0.1)^{2}\right), \mathrm{n}=343 /(1+343(0.01)), \mathrm{n}=343 /(1+3,43), \mathrm{n}=343 / 4,43, \mathrm{n}=77$ atau dibulatkan menjadi 77 orang

\section{Teknik Pengumpulan Data}

Data terbagi menjadi dua yaitu data primer dan data sekunder, yaitu : 1). Studi Pustaka. Menurut M.Nazir dalam bukunya yang berjudul 'Metode Penelitian' mengemukakan bahwa yang dimaksud dengan "Studi kepustakaan adalah teknik pengumpulan data dengan mengadakan studi penelaahan terhadap buku-buku, litertur-literatur, catatan-catatan, dan laporan-laporan yang ada hubungannya dengan masalah yang dipecahkan."(Nazir,1988: 111), 2). Studi Lapang. Dilakukan untuk memperoleh data primer yang langsung dari sumber data dengan penyebaran kuesioner/angket kuesioner yang disebarkan bersifat tertutup, maksudnya setiap pertanyaan telah disiapkan alternative jawabannya sehingga responden sudah mempunyai jawaban sesuai pendapatnya. Adapun gradasi jawaban yang disediakan mengacu pada skala likert.

\section{Teknik pengumpulan data}

Teknik pengumpulan data dilakukan dengan menggunakan kuesioner yaitu merupakan teknik pengumpulan data yang dilakukan dengan cara memberi seperangkat pertanyaan atau pernyataan tertulis kepada responden untuk dijawabnya (Sugiyono, 2005: 135). Sehubungan dengan penelitian ini peneliti, menyebarkan kuesioner kepada responden.

\section{Skala pengukuran}

Selanjutnya agar jawaban responden dapat diukur maka jawaban responden diberi skor. Dalam penelitian ini pemberian skor menggunakan skala Likert yaitu dengan menghadapkan seorang responden dengan sebuah pernyataan dan kemudian diminta untuk memberikan jawaban: "sangat setuju", "setuju”, "ragu-ragu", "tidak setuju”, "sangat tidak setuju” (Sugiyono, 2010 ).

Selanjutnya dalam prosedur skala Likert ini adalah menentukan skor atas setiap pertanyaan dalam kuesioner yang disebarkan. Jawaban dari responden dibagi dalam lima kategori penilaian dimana masing-masing pertanyaan diberi skor satu sampai lima. Dalam penelitian ini terdiri lima jawaban yangmengandung variasi nilai bertingkat, antara lain:

Tabel 2. Kriteria Penilaian dan Bobot nilai setiap pertanyaan

\begin{tabular}{lc}
\hline \multicolumn{1}{c}{ Alternatif Jawaban } & Bobot Nilai \\
\hline Sangat Baik / Sangat Setuju / Sangat Memuaskan / Selalu & 5 \\
Baik / Setuju / Memuaskan / Sering & 4 \\
Kurang Baik / Kurang Setuju / Kurang Memuaskan / Kadang- & 3 \\
kadang & 2 \\
Tidak Baik / Tidak Setuju / Tidak Memuaskan / Jarang & 1 \\
Sangat Tidak Baik / Sangat Tidak Setuju / Sangat Tidak & \\
Memuaskan / Tidak Pernah & \\
\hline
\end{tabular}

\section{Teknik Analisis Data}

Analisis Data adalah proses penyederhanaan data ke dalam bentuk yang lebih mudah dibaca dan diinterprestasikan setelah data dianalisis. Dalam penulisan skripsi ini, penulis melakukan penilitian dengan menggunakan analisis deskriftif kuantitatif dengan metode tabel frekuensi, yaitu menganalisa data dengan cara mendiskripsikan atau menggambarkan 100 data yang telah terkumpul dan 
menyajikannya dalam bentuk angka-angka tanpa bermaksud membuat kesimpulan yang berlaku umum. Adapun rumus yang digunakan untuk menganalisis tabel yaitu

$$
\mathrm{M}=\frac{\sum \mathrm{fx}}{\mathrm{n}}
$$

Keterangan $: \mathrm{f}=$ frekuensi, $\mathrm{M}=$ rata-rata, $\sum(\mathrm{fx})=$ jumlah skor kategori jawaban, $\mathrm{n}=$ jumlah responden

Hasil nilai skala interval tersebut disesuaikan dengan skala likert yang digunakan dalam penelitian. Adapun kriteria yang dimaksud adalah sebagai berikut:

Tabel 3. Kriteria Analisis Deskripsi

\begin{tabular}{cl}
\hline Rentang Kategori Skor & Penafsiran / kriteria \\
\hline $1,00-1,80$ & Sangat Tidak Baik \\
$>1,80-2,60$ & Tidak Baik \\
$>2,60-3,40$ & Cukup Baik \\
$>3,40-4,20$ & Baik \\
$>4,20-5,00$ & Sangat Baik \\
\hline
\end{tabular}

\section{Uji Keabsahan Data}

Setelah data terkumpul, selanjutnya akan dilakukan uji keabsahan data sebagai berikut :

\section{Uji Validitas}

Sebelum data diolah, terlebih dahulu harus dilakukan uji validitas yang digunakan untuk mengukur sah atau tidak sahnya suatu kuesioner. Kuesioner dikatakan valid apabila pertanyaan pada kuesioner mampu mengungkap sesuatu yang akan diukur oleh kuesioner itu. Dengan kata lain, suatu instrumen pengukuran dikatakan valid jika instrumen dapat mengukur sesuatu dengan tepat apa yang hendak diukur. Ada dua jenis validitas untuk instrumen penelitian, yaitu validitas logis (logical validity) dan validitas empiris (empirical validity). (Suharsirni Arikunto, 1993: 219).

Menurut Sugiyono (2003), validitas logis adalah validitas yang dinyatakan berdasarkan hasil penalaran. Instrumen dinyatakan berdasarkan memiliki validitas apabila dirancang dengan baik dan mengikuti teori dan ketentuan yang ada. Sedangkan validitas empiris adalah validitas yang dinyatakan berdasarkan hasil pengalaman. Sebuah instrument penelitian dikatakan memiliki validitas apabila sudah teruji dari pengalaman. Sebuah instrument penelitian dikatakan memiliki validitas apabila sudah teruji dari pengalaman.

Dengan demikian syarat instrument dikatakan memiliki validitas apabila sudah dibuktikan melalui pengalaman, yaitu melalui uji coba.

\section{Uji Reliabilitas}

Disamping melakukan uji validitas, selanjutnya harus pula dilakukan uji reliabilitas yang digunakan untuk mengukur suatu kuesioner yang merupakan indikator dari variabel. Dalam penelitian ini kuesioner dikatakan reliabel jika jawaban seseorang terhadap kuesioner stabil dari waktu ke waktu. Dengan kata lain uji reliabilitas digunakan untuk mengetahui ketepatan/ tingkat presisi suatu ukuran atau alat pengukur karena syarat untuk kualifikasi suatu instrumen pengukur adalah konsisten atau tidak berubah-ubah. Karena instrumen yang digunakan menggunakan jawaban berskala maka uji reliabilitas menggunakan croncbach Alpha.

Dengan kata lain, suatu instrument pengukuran dikatakan reliable jika pengukurannya konsisten (cermat) dan akurat. Dengan demikian uji reliabilitas instrument dilakukan dengan tujuan mengetahui konsistensi dari instrument sebagai alat ukur, sehingga hasil pengukuran dapat dipercaya. Hasil pengukuran dapat dipercaya hanya apabila dalam beberapa kali pelaksanaan pengukuran terhadap kelompok subjek yang sama (homogen) diperoleh hasil yang relative sama, selama aspek yang diukur dalam diri subjek memangbelum berubah. Relatif sama berarti tetap adanya toleransi terhadap perbedaan-perbedaan kecil diantara hasil beberapa pengukuran.

Sebuah faktor dinyatakan reliabel/andal jika koefisien Alpha lebih besar dari 0,6. Sebagaimana uji validitas, uji reliabilitas juga dilakukan dengan bantuan program SPSS. 
Setelah melakukan uji validitas dan reliabilitas dan dinyatakan valid, maka selanjutnya dilakukan pengolahan data. Pengolahan data merupakan suatu proses dalam memperoleh data ringkasan atau angka ringkasan dengan menggunakan cara atau rumus tertentu (Iqbal Hasan, 2002).

\section{Lokasi dan Jadwal Penelitian}

Tempat penelitian dilakukan di PT Nutrifood berlokasi di Kotamadya Bogor dari bulan Januari s/d Maret 2018.

\section{HASIL PENELITIAN DAN PEMBAHASAN}

\section{Deskripsi Responden}

Responden dalam penelitian ini adalah karyawan PT Nutrifood yang berjumlah sebanyak 77 orang responden dengan identitas sebagai berikut : jenis kelamin, dan usia.

\section{Jenis Kelamin}

Untuk mengetahui perbandingan antara jenis kelamin laki-laki dan perempuan, dapat dilihat pada tabel dibawah ini :

Tabel 5. Distribusi Responden Menurut Jenis Kelamin

\begin{tabular}{lcc}
\hline \multicolumn{1}{c}{ Jenis kelamin } & Frekuensi & Presentasi \\
\hline Laki-laki & 17 & 22,07 \\
Perempuan & 60 & 77,92 \\
Jumlah & 77 & 77 \\
\hline
\end{tabular}

Sumber : Data Primer yang diolah, 2018

Berdasarkan tabel dapat diketahui bahwa jumlah responden sebanyak 77 orang terdiri dari 54,54 $\%$ adalah laki-laki dan $45,45 \%$ adalah perempuan.

\section{Usia Responden}

Usia responden relatif homogen dengan kisaran umur antara $25 \mathrm{~s} / \mathrm{d} 60$ tahun.

\section{Hasil Penelitian}

Uji Validitas dan Reliabilitas Data Loyalitas Pelanggan

Uji Validitas

Uji validitas dilakukan dengan membandingkan nilai Corrected Item-Total Correlation terhadap nilai pada tabel $r$ Product Moment. Berdasarkan hasil uji validitas seperti yang pada lampiran 1, terlihat bahwa nilai $r>0,3$ sehingga hal ini menunjukkan bahwa butir-butir pertanyaan tersebut seluruhnya valid.

Uji Reliabilitas

Berdasarkan Uji reliabilitas seperti pada Lampiran 2, terlihat bahwa nilai Cronbach's Alpha yang nilainya lebih besar dari nilai $r=0,6$ sehingga dapat dikatakan reliable.

\section{Analisis Data Kondisi Kerja}

Berdasarkan penelitian mengenai loyalitas pelanggan yang penulis lakukan dimulai dengan melakukan penyebaran quesioner kepada responden yang berjumlah 77 orang untuk mengetahui loyalitas pelanggan di PT Nutrifood. Hasil jawaban dari responden tersebut kemudian penulis sajikan dalam bentuk tabel dibawah ini :

\section{Kepuasan terhadap produk}

Analisis kepuasan terhadap produk berdasarkan jawaban 77 responden diperoleh hasil perhitungan skor jawaban sebagai berikut : 
Tabel 6. Kepuasan Terhadap Produk

\begin{tabular}{cccccc}
\hline No & $\begin{array}{c}\text { Alternatif } \\
\text { Jawaban }\end{array}$ & $\begin{array}{c}\text { Frekuensi } \\
(\mathrm{F})\end{array}$ & $\begin{array}{c}\text { Bobot } \\
(\mathrm{x})\end{array}$ & $\mathrm{f}(\mathrm{x})$ & $\mathrm{M}=\sum \mathrm{f}(\mathrm{x})$ \\
\cline { 1 - 4 } 1 & Sangat Setuju & 37 & 5 & 185 & $\mathrm{n}$ \\
2 & Setuju & 40 & 4 & 160 & $\mathrm{n}=345$ \\
3 & Kurang Setuju & 0 & 3 & 0 & 77 \\
4 & Tidak Setuju & 0 & 2 & 0 & $=4,48$ \\
5 & Sangat Tidak & 0 & 1 & 0 & Sangat \\
& Setuju & 77 & & & \\
\cline { 2 - 3 } & Jumlah & & & &
\end{tabular}

Sumber : Data hasil Olahan, tahun 2018

Dari tabel diatas terlihat bahwa yang menyatakan sangat setuju ada 37 orang, setuju 40 orang, kurang setuju ada 0 orang, tidak setuju ada 0 orang, dan sangat tidak setuju ada 0 orang. Sehingga rata-rata kepuasan terhadp produk sebesar 4,48 yang termasuk kategori sangat baik. Hal ini disebabkan karena kualitas produk sudah baik dan sesuai dengan standar sehingga mampu memeunuhi kepuasan konsumen dengan baik

\section{Pembelian Berulang}

Analisis pembelian berulang berdasarkan jawaban 77 responden diperoleh hasil perhitungan skor jawaban sebagai berikut :

Tabel 7. Pembelian Berulang

\begin{tabular}{cccccc}
\hline No & Alternatif Jawaban & $\begin{array}{c}\text { Frekuensi } \\
(\mathrm{F})\end{array}$ & $\begin{array}{c}\text { Bobot } \\
(\mathrm{x})\end{array}$ & $\mathrm{f}(\mathrm{x})$ & $\mathrm{N}=\sum \mathrm{f}(\mathrm{x})$ \\
\cline { 1 - 4 } 1 & Sangat Setuju & 22 & 5 & 110 & $\mathrm{n}=323$ \\
2 & Setuju & 48 & 4 & 192 & 77 \\
3 & Kurang Setuju & 7 & 3 & 21 & $=4,19$ \\
4 & Tidak Setuju & 0 & 2 & 0 & Baik \\
5 & Sangat Tidak Setuju & 0 & 1 & 0 & \\
& Jumlah & 77 & & & \\
\hline
\end{tabular}

Sumber : Data hasil Olahan, tahun 2018

Dari tabel diatas terlihat bahwa yang menyatakan sangat setuju ada 22 orang, setuju 48 orang, kurang setuju ada 7 orang, tidak setuju ada 0 orang, dan sangat tidak setuju ada 0 orang. Sehingga rata-rata pembelian berulang sebesar 4,19 yang termasuk kategori baik. Hal ini disebabkan oleh karena pelanggan menilai kualitas produk sudah baik sehingga ia memutuskan untuk tetap membeli kembali produk PT Nutrifood.

\section{Kesetiaan Terhadap Produk}

Analisis kesetiaan terhadap produk berdasarkan jawaban 77 responden diperoleh hasil perhitungan skor jawaban sebagai berikut :

Tabel 8. Kesetiaan Terhadap Produk

\begin{tabular}{cccccc}
\hline No & $\begin{array}{c}\text { Alternatif } \\
\text { Jawaban }\end{array}$ & $\begin{array}{c}\text { Frekuensi } \\
(\mathrm{F})\end{array}$ & $\begin{array}{c}\text { Bobot } \\
(\mathrm{x})\end{array}$ & $\mathrm{f}(\mathrm{x})$ & $\mathrm{M}=\sum \mathrm{f}(\mathrm{x})$ \\
\cline { 1 - 4 } 1 & Sangat Setuju & 15 & 5 & 75 & $\mathrm{n}$ \\
2 & Setuju & 49 & 4 & 196 & $\mathrm{n}=310$ \\
3 & Kurang Setuju & 13 & 3 & 39 & 77 \\
4 & Tidak Setuju & 0 & 2 & 0 & $=4,03$ \\
5 & Sangat Tidak & 0 & 1 & 0 & Baik \\
& Setuju & 77 & & & \\
& Jumlah & & & & \\
\hline
\end{tabular}

Sumber : Data hasil Olahan, tahun 2018 
Dari tabel diatas terlihat bahwa yang menyatakan sangat setuju ada 15 orang, setuju 49 orang, kurang setuju ada 13 orang, tidak setuju ada 0 orang, dan sangat tidak setuju ada 0 orang. Sehingga rata-rata kesetiaan terhadap produk sebesar 4,03 yang termasuk kategori baik. Hal ini disebabkan karena pelanggan merasa puas terhadap produk PT Nutrifood sehingga tidak ada alasan untuk berpaling ke produk lain.

\section{Menggunakan Produk Lainnya}

Analisis menggunakan produk lainnya berdasarkan jawaban 77 responden diperoleh hasil perhitungan skor jawaban sebagai berikut :

Tabel 9. Menggunakan Produk Lainnya

\begin{tabular}{cccccc}
\hline \multirow{2}{*}{ No } & $\begin{array}{c}\text { Alternatif } \\
\text { Jawaban }\end{array}$ & $\begin{array}{c}\text { Frekuensi } \\
(\mathrm{F})\end{array}$ & $\begin{array}{c}\text { Bobot } \\
(\mathrm{x})\end{array}$ & $\mathrm{f}(\mathrm{x})$ & $\mathrm{M}=\sum \mathrm{f}(\mathrm{x})$ \\
\cline { 1 - 4 } 1 & Sangat Setuju & 12 & 5 & 60 & $\mathrm{n}$ \\
2 & Setuju & 54 & 4 & 216 & \\
3 & Kurang Setuju & 11 & 3 & 33 & $\mathrm{n}=309$ \\
4 & Tidak Setuju & 0 & 2 & 0 & 77 \\
5 & Sangat Tidak & 0 & 1 & 0 & $=4,01$ \\
& Setuju & 77 & & & Baik \\
& Jumlah & & & & \\
\hline
\end{tabular}

Sumber : Data hasil Olahan, tahun 2018

Dari tabel diatas terlihat bahwa yang menyatakan sangat setuju ada 12.orang, setuju 54.orang, kurang setuju ada 11 orang, tidak setuju ada 0 orang, dan sangat tidak setuju ada 0 orang. Sehingga rata-rata mengunakan produk lainnya kerja sebesar 4,01 yang termasuk kategori baik. Hal ini disebabkan karena konsumen menilai bahwa produk yang biasa ia beli sebelumnya memuaskan dirinya sehingga, ia mau mencoba untuk membeli produk lain dari PT Nutrifood.

\section{Menceritakan Kebaikan Produk kepada Orang lain tanpa Imbalan dari Perusahaan}

Analisis menceritakan kebaikan Produk kepada Orang lain tanpa Imbalan dari Perusahaan berdasarkan jawaban 77 responden diperoleh hasil perhitungan skor jawaban sebagai berikut :

Tabel 10. Menceritakan Kebaikan Produk Kepada Orang lain tanpa Imbalan dari Perusahaan

\begin{tabular}{|c|c|c|c|c|c|}
\hline No & $\begin{array}{c}\text { Alternatif } \\
\text { Jawaban }\end{array}$ & $\begin{array}{l}\text { Frekuensi } \\
\text { (F) }\end{array}$ & $\begin{array}{l}\text { Bobot } \\
\text { (x) }\end{array}$ & $f(x)$ & $M=\sum f(x)$ \\
\hline 1 & Sangat Setuju & 18 & 5 & 90 & \\
\hline 2 & Setuju & 48 & 4 & 192 & $\mathrm{n}$ \\
\hline 3 & Kurang Setuju & 11 & 3 & 33 & $\mathrm{n} \equiv 315$ \\
\hline 4 & Tidak Setuju & 0 & 2 & 0 & 77 \\
\hline \multirow[t]{2}{*}{5} & $\begin{array}{c}\text { Sangat Tidak } \\
\text { Setuiu }\end{array}$ & 0 & 1 & 0 & $\begin{array}{c}=4,09 \\
\text { Baik }\end{array}$ \\
\hline & Jumlah & 77 & & & \\
\hline
\end{tabular}

Sumber : Data hasil Olahan, tahun 2018

Dari tabel diatas terlihat bahwa yang menyatakan sangat setuju ada 18 orang, setuju 48 orang, kurang setuju ada 11 orang, tidak setuju ada 0 orang, dan sangat tidak setuju ada 0 orang. Sehingga rata-rata menceritakan kebaikan Produk kepada Orang lain tanpa Imbalan dari perusahaan sebesar 4,09 yang termasuk kategori baik. Hal ini disebabkan oleh karena ia telah merasakan kepuasan produk tersebut, dan saat ngobrol tentang produk dengan orang lain atau temannya, ia dengan sukarela menceritakan kebaikan/kualitas produk PT Nutrifood tersebut kepada orang lain/temannya.

\section{Merekomendasikan Produk kepada Orang Lain}

Analisis merekomendasikan produk kepada orang lain berdasarkan jawaban 77 responden diperoleh hasil perhitungan skor jawaban sebagai berikut : 
Tabel 11. Merekomendasikan Produk kepada Orang Lain

\begin{tabular}{|c|c|c|c|c|c|}
\hline No & Alternatif Jawaban & $\begin{array}{l}\text { Frekuensi } \\
\text { (F) }\end{array}$ & $\begin{array}{c}\text { Bobot } \\
(\mathrm{x})\end{array}$ & $f(x)$ & $M=\sum f(x)$ \\
\hline 1 & Sangat Setuju & 25 & 5 & 125 & $\begin{array}{c}\mathrm{n} \\
\mathrm{n} \\
-320\end{array}$ \\
\hline 2 & Setuju & 39 & 4 & 156 & $n=\frac{320}{77}$ \\
\hline 3 & Kurang Setuju & 13 & 3 & 39 & $=416$ \\
\hline 4 & Tidak Setuju & 0 & 2 & 0 & $\begin{array}{r}-4,10 \\
\text { Baik }\end{array}$ \\
\hline 5 & Sangat Tidak Setuju & 0 & 1 & 0 & \\
\hline & Jumlah & 77 & & & \\
\hline
\end{tabular}

Sumber : Data hasil Olahan, tahun 2018

Dari tabel diatas terlihat bahwa yang menyatakan sangat setuju ada 25 orang, setuju 39 orang, kurang setuju ada 13 orang, tidak setuju ada 0 orang, dan sangat tidak setuju ada 0 orang. Sehingga rata-rata merekomendasikan produk kepada orang lain sebesar 4,16 yang termasuk kategori baik. Hal ini disebabkan karena pelanggan telah merasa puas dengan produk PT Nutrifood dan menilai merasa layak untuk merekomendasikan kepada orang lain untuk membeli produk PT Nutrifood jika berbelanja ke mall/pusat perbelanjaan lainnya.

\section{Menginformasikan Pengalaman Baik Produk Kepada Pelanggan Potensial Lainnya}

Analisis menginformasikan pengalaman baik produk kepada pelanggan potensial lainnya berdasarkan jawaban 77 responden diperoleh hasil perhitungan skor jawaban sebagai berikut :

Tabel 12. Menginformasikan Pengalaman Baik Produk Kepada Pelanggan Potensial Lainnya

\begin{tabular}{|c|c|c|c|c|c|}
\hline No & Alternatif Jawaban & $\begin{array}{l}\text { Frekuensi } \\
\text { (F) }\end{array}$ & $\begin{array}{c}\text { Bobot } \\
\text { (x) }\end{array}$ & $f(x)$ & $M=\sum f(x)$ \\
\hline 1 & Sangat Setuju & 21 & 5 & 115 & n \\
\hline 2 & Setuju & 42 & 4 & 168 & $\frac{315}{77}$ \\
\hline 3 & Kurang Setuju & 14 & 3 & 42 & $=4.09$ \\
\hline 4 & Tidak Setuju & 0 & 2 & 0 & Baik \\
\hline 5 & Sangat Tidak Setuju & 0 & 1 & 0 & \\
\hline & Jumlah & 77 & & & \\
\hline
\end{tabular}

Sumber : Data hasil Olahan, tahun 2018

Dari tabel diatas terlihat bahwa yang menyatakan sangat setuju ada 21 orang, setuju ada 42 orang, kurang setuju ada 3 orang, tidak setuju ada 0 orang, dan sangat tidak setuju ada 0. orang. Sehingga rata-rata menginformasikan pengalaman baik produk kepada pelanggan potensial lainnya sebesar 4,09 yang termasuk kategori baik. Hal ini disebabkan karena ia menilai produk PT Nutrifood bermutu, dan menilai layak untuk menginformasikan kelebihan/kualitas produk PT Nutrifood tersebut kepada orang lain yang ia anggap potensial untuk menjadi pelanggan.

\section{Tidak Memiliki Keinginan Untuk Berpaling Melakukan Pembelian Produk Lain}

Analisis kondisi kerja berdasarkan jawaban 77 responden diperoleh hasil perhitungan skor jawaban sebagai berikut :

Tabel 13. Tidak Memiliki Keinginan Untuk Berpaling Melakukan Pembelian Produk Lain

\begin{tabular}{cccccc}
\hline No & $\begin{array}{c}\text { Alternatif } \\
\text { Jawaban }\end{array}$ & $\begin{array}{c}\text { Frekuensi } \\
(\mathrm{F})\end{array}$ & $\begin{array}{c}\text { Bobot } \\
(\mathrm{x})\end{array}$ & $\mathrm{f}(\mathrm{x})$ & $\mathrm{M}=\underline{\sum \mathrm{f}(\mathrm{x})}$ \\
\hline 1 & Sangat Setuju & 8 & 5 & 40 & $\mathrm{n}$ \\
2 & Setuju & 23 & 4 & 92 & $\mathrm{n}=\frac{262}{77}$ \\
3 & Kurang Setuju & 38 & 3 & 114 & $=3,40$ \\
4 & Tidak Setuju & 8 & 2 & 16 & Baik \\
5 & Sangat Tidak & 0 & 1 & 0 & \\
& Setuju & 77 & & & \\
& Jumlah & & & &
\end{tabular}

Sumber : Data hasil Olahan, tahun 2018 
Dari tabel diatas terlihat bahwa yang menyatakan sangat setuju ada 8 orang, setuju 23.orang, kurang setuju ada 38 orang, tidak setuju ada 8 orang, dan sangat tidak setuju ada 0 orang. Sehingga rata-rata tidak memiliki keinginan untuk berpaling melakukan pembelian produk lain sebesar 3,40 yang termasuk kategori baik. Hal ini disebabkan karena ia telah puasa dengan produk yang ia beli dari PT Nutrifood, sehingga tidak memiliki keinginan lagi untuk membeli produk yang sama dari perusahaan lain

\section{Melupakan Produk Perusahaan Lain}

Analisis melupakan produk perusahaan lain berdasarkan jawaban 77 responden diperoleh hasil perhitungan skor jawaban sebagai berikut :

Tabel 14. Melupakan Produk Perusahaan Lain

\begin{tabular}{cccccc}
\hline No & $\begin{array}{c}\text { Alternatif } \\
\text { Jawaban }\end{array}$ & $\begin{array}{c}\text { Frekuensi } \\
(\mathrm{F})\end{array}$ & $\begin{array}{c}\text { Bobot } \\
(\mathrm{x})\end{array}$ & $\mathrm{f}(\mathrm{x})$ & \multirow{\mathrm{M}}{\mathrm{M}}{$=\underline{\sum \mathrm{f}(\mathrm{x})}$} \\
\hline 1 & Sangat Setuju & 6 & 5 & 30 & $\mathrm{n}$ \\
2 & Setuju & 17 & 4 & 68 & $\mathrm{n}=252$ \\
3 & Kurang Setuju & 46 & 3 & 138 & 77 \\
4 & Tidak Setuju & 8 & 2 & 16 & $=3,27$ \\
5 & Sangat Tidak & 0 & 1 & 0 & Cukup \\
& Setuju & 77 & & & \\
& Jumlah & & & &
\end{tabular}

Sumber : Data hasil Olahan, tahun 2018

Dari tabel diatas terlihat bahwa yang menyatakan sangat setuju ada 6 orang, setuju 17 orang, kurang setuju ada 46 orang, tidak setuju ada 8 orang, dan sangat tidak setuju ada 0 orang. Sehingga rata-rata melupakan produk perusahaan lain sebesar 3,27 yang termasuk kategori cukup baik. Hal ini disebabkan oleh karena konsumen telah puas dengan kualitas produk PT Nutrifood, sehingga cukup mampu melupakan produk perusahaan lain.

\section{Ketidaktertarikan Terhadap Produk Lain dari Perusahaan lain}

Analisis ketidaktertarikan terhadap produk lain dari perusahaan lain berdasarkan jawaban 77 responden diperoleh hasil perhitungan skor jawaban sebagai berikut

Tabel 15. Ketidaktertarikan Terhadap Produk Lain dari Perusahaan lain

\begin{tabular}{|c|c|c|c|c|c|}
\hline No & Alternatif Jawaban & $\begin{array}{l}\text { Frekuensi } \\
\text { (F) }\end{array}$ & $\begin{array}{c}\text { Bobot } \\
(\mathrm{x})\end{array}$ & $f(x)$ & $\mathrm{M}=\sum \mathrm{f}(\mathrm{x})$ \\
\hline 1 & Sangat Setuju & 4 & 5 & 20 & $n$ \\
\hline 2 & Setuju & 11 & 4 & 44 & $n=242$ \\
\hline 3 & Kurang Setuju & 54 & 3 & 162 & 77 \\
\hline 4 & Tidak Setuju & 8 & 2 & 16 & $=3,14$ \\
\hline 5 & Sangat Tidak Setuju & $\begin{array}{c}0 \\
77\end{array}$ & 1 & 0 & Cukup baik \\
\hline
\end{tabular}

Sumber : Data hasil Olahan, tahun 2018

Dari tabel diatas terlihat bahwa yang menyatakan sangat setuju ada 4 orang, setuju 11 orang, kurang setuju ada 54 orang, tidak setuju ada 8 orang, dan sangat tidak setuju ada 0 orang. Sehingga rata-rata ketidaktertarikan terhadap produk lain dari perusahaan lain sebesar 3,14 yang termasuk kategori cukup baik. Hal ini disebabkan karena ia puas dengan produk PT Nutrifood, sehingga tidak cukup tertarik lagi untuk melakukan pembelian produk yang sama dari perusahaan lain, karena ia tidak mau berspekulasi membeli yang akhirnya bisa mengecewakannya.

\section{Rekapitulasi Analisis Loyalitas pelanggan}

Rekapitulasi keseluruhan pembahasan mengenai analisis loyalitas pelanggan PT Nutrifood diketahui pada tabel dibawah ini : 
Tabel 16 Analisis Loyalitas pelanggan

\begin{tabular}{|c|c|c|c|}
\hline No & Indikator & Skor & Rata-rata \\
\hline 1 & Kepuasan terhadap produk PT Nutrifood & 4,48 & Sangat Baik \\
\hline 2 & Selalu melakukan pembelian berulang PT Nutrifood & 4,19 & Baik \\
\hline 3 & Selalu setia terhadap produk PT Nutrifood & 4,03 & Baik \\
\hline 4 & Menggunakan produk PT Nutrifood lainnya & 4,01 & Baik \\
\hline \multirow[t]{2}{*}{5} & Menceritakan kebaikan-kebaikan jasa layanan PT & & \\
\hline & $\begin{array}{l}\text { Nutrifood yang kepada orang lain, tanpa adanya } \\
\text { timbal balik dari perusahaan }\end{array}$ & 4,09 & Baik \\
\hline 6 & $\begin{array}{l}\text { Merekomendasikan produk PT Nutrifood kepada } \\
\text { orang lain }\end{array}$ & 4,16 & Baik \\
\hline 7 & $\begin{array}{l}\text { Menginformasikan pengalaman baik anda atas produk } \\
\text { PT Nutrifood kepada pelanggan potensial lainnya }\end{array}$ & 4,09 & Baik \\
\hline 8 & $\begin{array}{l}\text { Tidak memiliki keinginan untuk berpaling melakukan } \\
\text { pembelian produk selain selain produk PT Nutrifood }\end{array}$ & 3,40 & Baik \\
\hline \multirow{3}{*}{$\begin{array}{c}9 \\
10\end{array}$} & Melupakan produk perusahaan lain & 3,27 & Cukup Baik \\
\hline & $\begin{array}{l}\text { Cenderung menunjukkan ketidak tertarikan terhadap } \\
\text { produk lain atau jasa sejenis dari perusahaan lain }\end{array}$ & 3,14 & Cukup Baik \\
\hline & Rata-rata skor & 3,89 & Baik \\
\hline
\end{tabular}

Sumber : Data hasil Olahan, tahun 2018

\section{Pembahasan}

Dengan melibatkan sebanyak 77 orang responden, memberikan informasi mengenai loyalitas pelanggan. Dari hasil di atas, secara umum dapat disimpulkan bahwa ternyata loyalitas pelanggan sudah baik, dimana nilai dalam skala likert ditunjukkan dengan besaran sebesar 3,89 ( baik). Dari data di atas jelaslah sudah bahwa loyalitas pelanggan PT Nutrifood sudah baik, loyalitas pelanggan tersebut sangat strategis karena maju mundurnya PT Nutrifood tergantung dari loyalitas pelanggan. Semakin tinggi tingkat loyalitas pelanggan karya wan, semakin besar peluang lembaga untuk menjaga eksistensi dan pengembangan usahanya ke depan.

Kita menyadari bahwa loyalitas pelanggan merupakan faktor yang menentukan eksisitensi perusahaan, karena kita mengetahui bahwa kehadiran persaingan usaha diantara perusahaan lainnya berjalan sangat ketat, sehinga disadari atau tidak, langsung maupun tidak langsung, loyalitas pelanggan akan menjadi faktor yang sangat menentukan pelanggan dalam memilih layanan. Dengan demikian faktor loyalitas pelanggan tersebut haruslah disikapi dengan bijak oleh setiap perusahaan, jika ingin perusahaan tersebut tetap eksis, maju dan berkembang. Kita mengetahui bahwa setiap perusahaan senantiasa berusaha semaksimal mungkin untuk menjaring perolehan jumlah pelanggan sebanyak-banyaknya. Berbagai upaya dilakukan perusahaan melalui promosi untuk menjaring minat pelanggan, salah satu diantaranya adalah dengan memenuhi harapan mereka, sehingga diperlukan loyalitas pelanggan yang tinggi.

PT Nutrifood memahami betul bahwa tujuan perusahaan diarahkan untuk meningkatkan loyalitas pelanggan perusahaan melaui peningkatan kualitas produk dan kualitas pelayanan yang baik, karena loyalitas pelanggan memainkan peranan yang sangat penting dalam mencapai kemajuan perusahaan. PT Nutrifood memahami betul bahwa banyak faktor-faktor penting yang mempengaruhi loyalitas pelanggan sehingga perlu selalu melakukan pengukuran loyalitas pelanggannya, karena loyalitas pelanggan memainkan peran yang sangat penting bagi peningkatan atau suatu perubahan kemajuan perusahaan ke arah yang lebih baik. Pengukuran atau penilaian loyalitas pelanggan dilakukan dengan menilai perusahaan apakah berhasil atau tidak demi perbaikan loyalitas pelanggan pada masa yang akan datang. Tujuan pokok pengukuran loyalitas pelanggan adalah untuk memperbaiki kinerja perusahaan perusahaan, sehingga ke depan kelemahan-kelemahan perusahaan dalam bisa dibenahi guna meningkatkan loyalitas pelanggan. 


\section{KESIMPULAN DAN SARAN}

\section{Kesimpulan}

Berdasarkan hasil penelitian, loyalitas pelanggan PT Nutrifood sudah baik, hal tersebut terlihat dari skor rata-rata loyalitas pelanggan sebesar 3,89.

\section{Saran}

Dari hasil penelitian diatas loyalitas pelanggan PT Nutrifood sudah baik, namun untuk lebih meningkatkan loyalitas pelanggan agar hasilnya lebih maksimal, maka perusahaan perlu memperbaiki dan meningkatkan point-point yang nilainya masih di bawah rata-rata yaitu sebagai berikut : 1). Keinginan konsumen untuk berpaling melakukan pembelian produk selain selain produk PT Nutrifood, 2). Kemampuan konsumen untuk melupakan produk perusahaan lain, dan 3). Ketidak tertarikan konsumen terhadap produk lain atau jasa sejenis dari perusahaan lain.

Untuk meningkatkan point-point di atas, perusahaan perlu segera melakukan dan meningkatkan upaya untuk semakin memperbaiki kualitas barang, kualitas kemasan, kualitas pelayanan, penyesuaian harga yang lebih marketable yang lebih terjangkau oleh konsumen serta promosi yang gencar lewat media iklan.

\section{DAFTAR PUSTAKA}

Ahmad Mardalis, 2005, "Meraih Loyalitas Pelanggan", Benefit: Jurnal Manajemen dan Bisnis, FE UMS Surakarta, Volume 9, No. 2, Desember, p. 111-119.

Alida Palilati, 2004, "Pengaruh Tingkat Kepuasan Terhadap Loyalitas Nasabah Tabungan Perbankan Di Wilayah Etnik Bugis", Jurnal Ekonomi, Universitas Haluoleo, Kendari, Volume 1, Nomor 2, Maret 2004. (http://www. pascaunhas.net)

Barnes, James G., 2003, Secrets of Customer Relationship Management (Rahasia Manajemen Hubungan Pelanggan, alih bahasa: Andreas Winardi, Andi Offset, Yogyakarta.

Basu Swastha DH. dan Irawan, 2001, Manajemen Pemasaran Modern, Liberty, Yogyakarta. Cooper,

Donald R. and C. William Emory, 1995, Business Research Methods, 5th Ed, Chicago :

Richard D. Irwin, Inc. Freddy Rangkuti, 2004, Flexible Marketing, PT. Gramedia Pustaka Utama, Jakarta.

Gefen, David, 2002, "Customer Loyalty in E-Commerce", Journal of the Association for Information Systems, Volume 3, p.27-51. (http://bebas.vlsm. org)

Hendri Ma'ruf, 2006, Pemasaran Ritel, PT. Gramedia Pustaka Utama, Jakarta.

Jogiyanto, 2004, Metodologi Penelitian Bisnis: Salah Kaprah Dan Pengalaman Pengalaman, BPFE, Yogyakarta.

Kotler, Philip, 2000, Manajemen Pemasaran, Analisis, Perencanaan, Implementasi dan Kontrol Jilid 1, Alih bahasa: Imam Nurmawan, Edisi Ketiga, PT. Prenhallindo, Jakarta.

Mowen, John C. dan Minor, Michael, 2002, Perilaku Konsumen, Alih bahasa: Dwi Kartini Yahya, Erlangga, Jakarta.

Muafi, 2003, "Mengelola Kepribadian Merek", Jurnal Telaah Bisnis Akademi Manajemen Perusahaan YKPN, Yogyakarta Volume 4, Nomor 1, Juli

Riana Iswari dan Retno Tanding Suryandari, 2003, "Analisis Pengaruh Citra Supermarket terhadap Loyalitas Konsumen”, Jurnal Bisnis dan Manajemen UNS, Vol. 3, No. 2, Surakarta, November. 